\title{
Taxonomical and pharmacological status of Typha: A Review
}

Amit Pandey and R.K. Verma

Dept. of Botany, Bundelkhand University, Kanpur Road, Jhansi, India.

Received: 1/30/2018; Accepted: 2/21/2018

\begin{abstract}
Cattail or Typha is a genus of plants. It is found in wetland habitats. They are usually found in the Northern Hemisphere, but sometimes found in wetlands elsewhere. These plants recognized in British English as reedmace or bullrush and in American English as punks or cattail. In North America 3 species are well known, $T$. latifolia (broadleaf cattail), T. angustifolia (narrow leaf cattail), and southern cattail (T. dominensis). Broadleaf and southern cattails are considered native to North America. All three species are early colonizers of wetlands and compete with native wetland herbs because of their seeds dispersed by wind and rapid growth of their underground stems (rhizomes). Cattails were once used to make paper. Cattail paper is very heavy and coarse, and is rarely used today. Toxic chemical such as arsenic from drinking water has been removed by cattail because it serve as water filter. The current review discuss with the origin, distribution, chemical composition, taxonomic status and pharmacological studies.
\end{abstract}

Key words: Cattail, Typha, T. latifolia, Typha angustifolia.

\section{Introduction}

30 species of genus Typha belongs to family Typhaceae is known. These plants also known as, reedmace or bulrush in British English (NRCS, 2015) cattail in American English (Revedin et al., 2010) punks, or corn dog grass, bulrush or cumbungi in Australia as, cattail or bulrush in Canada. The genus is spread in most part of the Northern Hemisphere, where it is found in a variety of wetland habitats. Its rhizome is edible. Evidence of preserving starch grains on grinding stones indicate that they were eaten 30,000 years ago in Europe. (Revedin et al., 2010

Cattail or Typha exist in form of different species. Broad-leaved cattail, common cattail (Typha latifolia L.) can be found in relatively habitats which are undisturbed, whereas narrowleaved cattail. (Typha angustifolia L) and the hybrid, Typha $\mathrm{x}$ glauca, usually found in more unstable and saline habitat (Grace and Harrison 1986.) Management action are usually the same for all 3 species. It is one of the most frequent and simply recognized of our water-loving plants. Most of the human are well-known with the long green leaves and hot-dog shaped brown flower spikes of our cattail, Typha latifolia. Plant is widespread, occur in most of Europe, Asia, North America, and Africa.

Narrow leaf cattail or T. angustifolia are other species which are harbours by Washington. It is an invader from different parts of the nation, and until now is only well known from a couple of location.

\footnotetext{
*Corresponding Author:

Amit Pandey,

Research Scholar, Dept. Of Botany,

Bundelkhand University, Kanpur Road,

Jhansi, India.

E-mail: pandeyamit0076@gmail.com
}

Cattails are frequently a thought as an aggravation along lake side. However, they what's more different shoreline plants could worth of effort critical work which keeps a lake solid. Person such playing point will be they strain overflow Likewise it streams under the lake. This aides lessen supplements and also mud which enter lakes starting with encompassing area. They also assistance prevent shoreline disintegration starting with waves made by air. A solid plant group along the shoreline camwood fill in wonders for keeping lakefront property soundness. Clinched alongside addition, cattails furnish critical habitat for numerous species about untamed life and winged creatures. Redwing blackbirds and huge numbers ducks also geese home previously them, furthermore some animals for example, muskrats, consume them. Significantly upland songbirds will utilize cushion from those blooms will offering their nests.

A standout amongst those mossycup oak in triguing viewpoints over cattails may be how people need utilized this plant through those hundreds of years. Should quote an punctual advocate about regular foods, 'most of the parts are edible. On spring the root stocks also rhizomes were a critical nourishment sourball for local people groups At different nourishment might have been rare. These foundations need aid exactly nutritious, holding more starch over potatoes. Furthermore more protein over rice. The junior shoots need aid appeared for make wonderful Likewise cooked vegetables, and the pollen might a chance to be utilized within heated merchandise. Furthermore 
with food, cattails bring likewise give people with building materials. The dried abandons were frequently woven under furniture what's more mats, furthermore their mash \& also fibers could make constructed under paper and string. Considerably that cushion starting with the seed heads need been utilized for padding, padding what's more encasing. Cattails also have medicinal value, numerous societies have utilized those foundations on treat intestinal maladies and smolders.

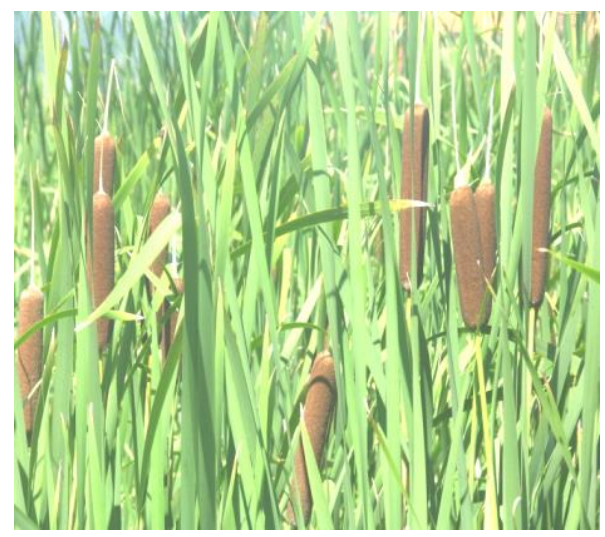

Fig. 1: T. latifolia

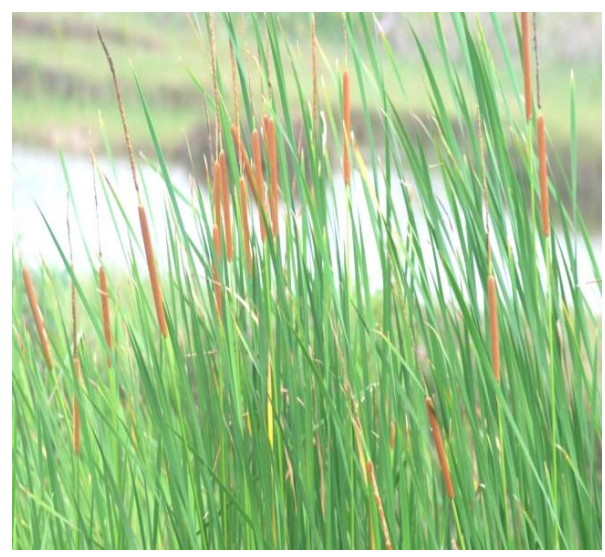

Fig. 2: T. angustata

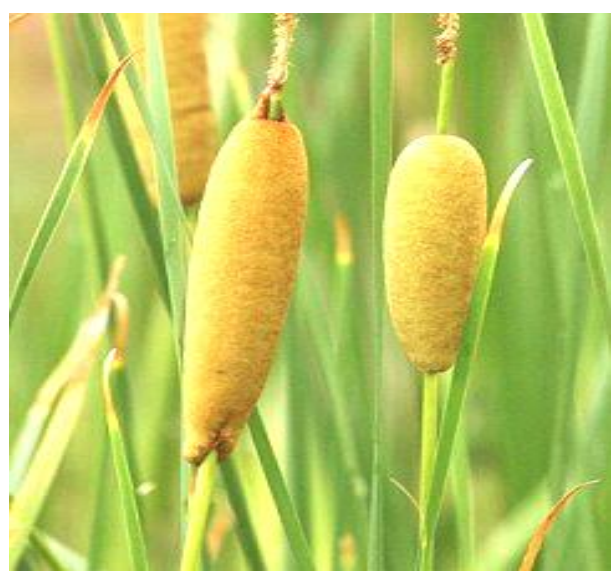

Fig. 3: Typha $\times$ glauca

\section{Ecology:}

Typha need aid frequently all around those to begin with wetland plants on colonize zones from claiming recently uncovered wet mud, for their plentiful seeds dispersed by air. Covered seeds might survive in the dirt to in length periods of time (Van der Valk et al., 1976). They germinate best with daylight what's more fluctuating temperatures, which will be ordinary about huge numbers wetland plants toward recover for mud flats (Shipley et al., 1989). The plants also spread Eventually Tom's perusing rhizomes, framing large, inter connectedness stands.

Typha would recognized to a chance to be prevailing contenders previously, wetlands in numerous region, also they usually avoid different plants with their shade (Keddy, 2010). Different species of cattaili would adjusted will different water depths. (Grace and Wetzel, 1981). Proper progressed aerenchyma makes the plants acceptable of submersion. Even the non-living stalks are able of transmit $\mathrm{O}_{2}$ to the rooting area.

In spite of typha are local wetland plants, they could a chance to be Combative clinched alongside their rival for different local species (Oudhia, 1999). They have been problematic in numerous areas on $\mathrm{N}$. America, from the great Lakes of the everglades (Keddy, 2010). Local sedges are displaced also wet meadows shrink, liable similarly as an light of modified hydrology of the wetlands, furthermore expanded supplement levels. An acquainted or mixture species might be helping of the issue (Boers, 2007). Control is challenging. The greater part effective technique gives the idea with he mowing alternately smoldering with uproot those aerenchymous stalks, trailed by prolonged flooding (Kaminski. et al., 1985). It might be more significant on keep attack by preserving water level fluctuations, including periods of drought, what's more on support fruitless states (Keddy, 2010). Typha need aid habitually consumed toward wetland mammals for example, muskrats, that also use them on develop bolstering platforms and dens, giving nesting what's more resting spots for waterfowl. (Global Invasive Species Databace, 2017).

Edible parts: Flowers, Stem, Leaves. Root, Pollen, Seed.

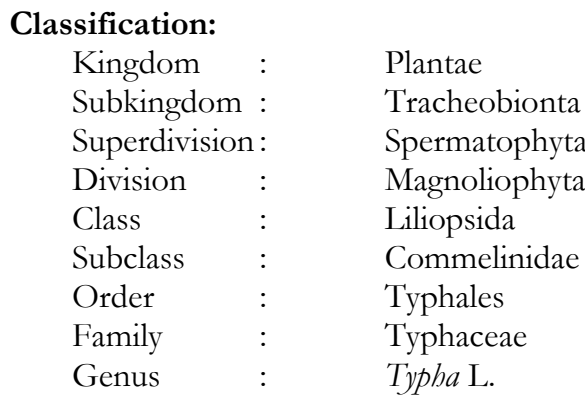




\section{Discription:}

This lasting plant is something like 4-9' tall and unbranchcd, comprising about 6 or additional abandons also blooming stalk. This stalk is lip, should green, glabrous, stiff, and round clinched alongside cross- segment (terete). The abandons need aid up to $7 \mathrm{~m}$ in length. They need aid linear, green to pale blue ash (often the latter), hairless, what's more rather smoothed. The moment flowers, grouped together under spikes, manifestation. An barrel shaped inflorescence with those staminate (Male) blossoms placed over the pistillate (Female) blossoms (Stevens \& Hoag, 2000). Those rosy should blackish-brown staminate blossoms camwood make 7 to $13 \mathrm{~cm}$ long, inasmuch as the dim tan pistillate blooms develop between 2.5-20 $\mathrm{cm}$ in length (Mitich, 2000). Relative of the blooming stalk, the abandons need aid erect with marginally spreading; they begin from the base of the plant. A few abandons have an propensity to flop descending at their tips. Leaf beet venation may be parallel. There may be an sheath at the base of every leaf beet. Those blooming stalk terminates done a spike from claiming staminate blooms furthermore an spike of pistillate blossoms. The staminate spike is over those pistillate spike; they are contiguous alternately divided eventually Tom's perusing $1 / 2$ " or lesquerella. The staminate spike is dependent upon $1 \mathrm{~m}$ in length. It may be narrowly barrel in shape, light yellow should light brown, (Mitich 2000; Grace and harrison 1986: Motivans and Apfelbaum 1987). Also thickly stuffed for staminate blossoms what's more abundant hairs. Every staminate bloom bears 4 grains of pollen; its petals Furthermore sepals are diminished with bristles. Following those pollen is released, the staminate spikequickly withers far. Thepistillate spike may be may be up to $1 / 2$ ' long; it may be barrel shaped Previously, shape, greenish will blackish brown, Also thickly stuffed for pistillate blossoms Also abundant hairs. Each rich pistillate bloom need An stipe no less than $1 \mathrm{~mm}$. Long, a solitary ovary, and, an single style with an leveled shame. Fruitless pistillate blooms absence achenes, generally they need aid comparable of the rich pistillate blooms.

\section{Habitat and Distribution}

Cattail population might a chance to be found all around those world, commencing tropical to calm /ones. Furthermore, from muggy to dry atmospheres. Their tolerance will changing climatic states Furthermore natural transforms serves them attain broad predominance done an assortment about oceanic plant communities (Mitich 2000; Murkin \& Ward 1980). Cattails could happen to whatever put the place the soil left overs wet alternately saturated: roadside ditches, wet meadows, reservoirs, lakeshores, marshes, bogs, etc, (Grace \& Harrison, 1986). In spite of, cattail will be a freshwater oceanic plant, it might endure exactly level from claiming saltiness and acridity (Grace \&
Harrison 1986). It may be likewise tolerant for lasting flooding, poor soil states (Stevens Furthermore Hoag 2000), Also secondary focuses of $\mathrm{Pb}, \mathrm{Zn}, \mathrm{Cu}$, furthermore $\mathrm{Ni}$. (Motivans and Apfelbaum, 1987).

Tvpha latifolia camwood make discovered previously, moderately undisturbed habitats, as much as Typha angustifolia regularly happens to additional flimsy what's more saline situations (Grace \& Harrison, 1986). As stated by Wilcox et al., (1984), Typha angustifolia will be recognized a pioneer on auxiliary progression about exasperates bogs. At those two species happen together, Typha angustifolia will be by confined on deeper waters Furthermore All the more saline states. Typha lantifolia thrives for shallow water. Their mixture species, typha $\times$ glauca, need comparable habitat necessities will $T$. angustifolia (Motivans and Apfelbaum, 1987). T. latifolia camwood be discovered in oceanic groups in the least stages, starting with promptly with late successional, while T. angustifolia also Typha $\times$ glauca regularly happen clinched alongside early should mid successional groups furthermore are habitually discovered in exasperates wetland destinations (Grace and Harrison, 1986).

As stated by Grace \& Harrison, 1986, constantly on species for Typha spp. Camwood happen previously, dense, monospecific stands, alternately similarly as spread individuals, alternately clumps for stands of blended vegetation Spp. Is often encompassed by alternately intermixed for other plants for example, Phragmites australlis, Lythrum salicaria, Spartina sp., Acorns calamus, Scripus sp., what's more Sagittaria latifolia (Motivans and Apfelbaum, 1987). Those dissemination of the three-different species varies over North America. Dependent upon until the conclusion of the nineteenth century, T. angustifolia might have been restricted to the eastern drift from claiming northern $\mathrm{N}$. america. Since then, $T$. angustifolia need spread inland and westward getting to be broad all around canachites canadensis and the northern United States, bringing about expanded blending for T. Latifolia, and the resulting processing what's more spread for hybrids. (Grace and Harrison, 1986).

\section{Molecular and Supermolecular Structure:}

The rhizome of basic cattail might have been reaped in the spring from an common pond. Those starch might have been disconnected toward grinding and washing_away those fiber portion. Sonication might have been used to crumble those Mobile dividers. Those structure of starch granules might have been examined utilizing those filtering electron microscopy (SEM) also totally point Xbeam dissipating system (WAXS). Those subatomic impostor dissemination of the starch macromolecules might have been analysed with gel penetrating chromatography utilizing triple, identification Also contrasted with effects from 
claiming corn also potato starches. The pantiles of the cattail starch were round formed and needed an ordinary gaussian appropriation from claiming size described by a mode esteem about those WAXS examination demonstrated that the granules required an kind precious stone structure, which might have been a consolidation of a what's more be polymorphs helping $18.3 \% \& 71.7 \%$ resp. Those cattilstarch held $32 \%$ amylase. Its sub-atomic impostor might have been essentially higher over potato starch be that marginally easier over corn starch. The sub-atomic impostor for cattil amylopectin might have been the middle of corn what's more potato starch. Its structure might have been the greater part ranched contrasted with every last one of starches investigated. (Kurzawska et al., 2014).

\section{Antimicrobial Activity:}

Antimicrobial activity was done by using disc diffusion method by using Mueller Hinton Agar. The Methanolic extract shows remarkably good activity against against E.coil and moderate antimicrobial activity against Staphylococcus aureus. The methanolic extract also showed moderate antimicrobial activity against $A$. flavus (Varghese et al., 2009).

\section{Anti-Inelaniniatory Activity:}

The abandons for Typha angustifolia (100, 200, 400 $\mathrm{mg} / \mathrm{kg}$ p.o.) altogether (i) <- 0.05 ) repressed carrageenan prompted paw edema. Yet the methanol extricate indicated the greatest restraint of carrageenan prompted rodent paw edema when contrasted with those control bunch. The Methanolic extricate likewise demonstrated noteworthy inhibiton for histamine prompted rodent paw edema at contrasted with control aggregation. Subsequently greatest mitigating impact about abandons for Typha angustifolia might a chance to be attributed of the vicinity about falvonoids. (Pawar et al., 2011).

\section{Pharmacognostical Evaluation:}

Typha angustifolia might have been concentrated on fix its quantitative measures such as dampness content, downright ash, extractive values and its microscopical investigations once abandons and powder qualities were likewise directed on the aerial parts of the plants. The results are shown in the table below (Varghese et al., 2009).

\begin{tabular}{lcc}
\hline S.No. & Parameters (\%) & Interference \\
\hline 1. & Loss on drying & 8.21 \\
2. & Total Ash & 11.15 \\
3. & Water soluble value & 16.8 \\
4. & Alcohol value & 33.6 \\
5. & Acid insoluble Ash & 0.54 \\
\hline
\end{tabular}

\section{Phytoremediation:}

The examination for Typha latifolia's absorption limit if that, in the event that of Nickel, Chromium, Copper also Arsenic, a low ability of overwhelming metals absorption might have been distinguished. Those test qualities got were a great part bring down concerning illustration contrasted with the individuals distinguished in the soil tests. To the same plant, a acceptable absorption (capacity might have been identifier in the event from claiming overwhelming metals for example, such that Cadmium, Lead, Zinc also Mercury. Typha latilofolia as tounding absorption ability for overwhelming metals starting with the soil might have been recorded in the event for Cadmium Typha latilofolia might a chance to be utilized within dirt phytoremediation courses especially in phyloextraction procedures (a system utilized to those evacuation from claiming overwhelming metals starting with defiled sods). Since it is a sery handy gatherer about overwhelming metals on the harvestable side, ahead waterway banks, taking under record those extension of the domain where they place these plants. (Chijimus et al., 2011).

\section{Uses}

a) Seating chair: The rushes are reaped and the abandons regularly dry for after the fact use over seat. Re-wetted, those abandons need aid turned. Also wrapped around the seat rungs to structure an thickly woven seat that is then stuffed. (Usually with the left-over rush).

b) Culinary uses: Mostly parts of the Typha plant are edible to humans.

- Rhizomes is starchy with an protein content around to that of maize or rice (Morton, 1975). They camwood make transformed under a flour with $266 \mathrm{kcal} / 100$ grams. They need aid mossycup oak regularly reaped starting with late harvest time with promptly spring. They are fibrous, and the starch must a chance to be scratched alternately sucked starting with the intense fibers.

- Plants developing done dirtied water accumulate a mass lead what's more pesticide residues on their rhizomes, furthermore these bolstering not make consumed. (Gore, 2007).

- The external parcel from claiming adolescent plants could a chance to be peeled and the heart camwood a chance to be consumed crude alternately bubbled Furthermore consumed such as Asparagus. This sustenance need been well known Around the Cossacks to Russia, also called "Cossack asparagus"(Marsh, 1959).

- Those leaf beet bases could a chance to be consumed crude alternately cooked, particularly done late spring the point when they are junior furthermore youthful.

- Clinched alongside promptly Spring those sheaths could be uprooted starting with those Creating green bloom spike, which might afterward be bubbled and consumed in corn on the cob (Elias \& Dykeman, 2009). 
- On mid-summer at those male blooms need aid mature, the pollen might a chance to be gathered what's more utilized. Similarly, as an flour supplement alternately thickener (Raupo \& Bulrush, 2011).

- Those establishes might additionally a chance to be boiled, steamed, fried, alternately mashed for spread or sharp cherry tree a great part such as potatoes.

c) Agriculture: The Seeds bring an helter skelter linoleic acid content, furthermore have a chance to be used to bolster cows and chickens (Reed \& Marsh, 1955). They can also be occur in Ghana.

d) Building material: To nearby tribes around Lake Titicaca on Bolivia and Peru, Typha were around those practically vital plants and all aspects of the plant needed various employments. For example, they were used to develop pontoons what's more other boats (Morton, 1975). Throughout universe War II, the United States war fleet utilized those down for typha likewise an substitute for kapok in life vests Furthermore aeronautics jackets. Tests indicated that considerably following 100 hours about submersion the buoyancy might have been still powerful (Miller, 1999). Typha would utilized Concerning illustration warm encasing done structures. Similarly as an natural elective should customary insulating materials for example, glass wool or stone wool.

e) Paper: Tupha stems what's more abandons could a chance to be used to aggravate paper. It will be solid for a overwhelming composition and it is difficult to bleach, something like that it may be not suitableness for modern handling from claiming graphical paper. Previously, 1853, significant sums of cattail paper were prepared over New York, because of a lack for crude materials. (National investigate board. Books to benefits of the business, 1976) clinched alongside 1948, french researchers tried strategies for twelve-month collecting of the abandons. Due to the helter skelter expense these routines were deserted and no further Scrutinize might have been carried out (Morton, 1975). Today Typha is used to settle on enlivening paper.

f) Fiber: Fibers dependent upon $4 \mathrm{~m}$ in length could be acquired from the stems when they need aid mechanically or synthetically approached for sodium hydroxide. Those originate fibers look like jute what's more could be used to prepare crude materials. Those leaf beet fibers might make utilized as an elective with cotton. The yield for leaf beet fiber may be 30 to 40 percent and Typha x glauca might transform 7 to 10 tonsil for every hectare yearly (Morton, 1975).

g) Biofuel: Typha might make utilized concerning illustration an wellspring for starch to prepare ethanol. Due to their helter skelter profit for northern plains latitudes, typha would acknowledged will make an bioenergy crop. (Dubbe, 1998).

h) Other Uses: Those seed hairs were utilized by exactly indigenous kin of the Americas concerning illustration tinder to beginning blazes. Exactly tribes likewise utilized Typha down on accordance slippers what's more utilized for bedding, diapers, infant powder also support sheets. One local American expression Typha intended “fruit for papoose's bed". Typha down is still utilized within a few territories should stuff apparel things Also pillows. Typha could a chance to be dipped on wax alternately fat et cetera lit Likewise a candle, the originate serving as a wick. Without the utilization about wax alternately fat it will seething slowly, to some degree similar to incense Also might repellant insects. Person casual test need shown that Typha have the capacity will uproot arsenic from drinking water. The bubbled rootstocks bring been utilized Likewise an diuretic to expanding pee alternately mashed and formed an jelly-like pasta sauce for sores, boils, wounds, burns, scabs, and smallpox pustules. (Maiden, 1889).

i) Use of Cattil Rhizome: The greater part notable sustenance that hails from the cattail may be its rhizome, an root-like, underground stem that is a standout amongst those wealthiest wild sources about eatable carbohydrates in the northeast. The centre of the thick expanding rootstock, which grows horizontally in the mud, is starchy. It camwood make cooked furthermore consumed as potatoes, alternately dried and ground under flour utilized within heating. Also as a substitute for corn starch. This flour could make aged to process ethyl liquor important as anti-freeze. Similarly, as an Shabby streamlined solvent, what's more for medicinal purposes. It contains more fat but slightly less protein than potato or wheat flours, and only potato flour has more minerals

\section{References}

1. Agata Kurzawska, Danuta Gorecka, Wioletta Blaszczak, Artur Szwengiel. Dominik Paukszta., Gra2yrna Lewandowiez. The molecular and supermolecuiar structure of common cattail (Typha latifolia) starch. Starch-starke.2014, 66, 849-856.

2. Alexandra-Dana Chitimus, Cristian Radu, Valentin Nedeff, Emilian Mosnegutu, Narcis Barsan. Studies and Researches on Typha latifolia's (bulrush) Absorption Capacity of Heavy Metals from the soil, St. Cerc. St. CICBIA. 2016, 17 (4), 381-393.

3. Alexeyena Varghese, Usha Gavania, Suja Abraham, Della Grace Thomas Parambi, Sathianarayanan and Asha Jose. Phytochemical Screening and Antimicrobial Investigation of Typha angustifolia Linn. Int. J. Chem. Sci. 2009,7(3), 1905-1910 
4. Boers, A. M., et al., Typha x glauca dominance and extended hydroperiod constrain restoration of wetland diversity. Ecological Engineering 2007, 29, 232-44,

5. Clegg. J.Observer's Book of Pond Life. Frederick Warne, London. 1986, 460.

6. Dubbe, D. R., et al., Production of cattail (Typha spp.) biomass in Minnesota, USA. Biomass 1988, 17(2), 79-104.

7. Elias, T. S.; Dykeman, P. A. Edible Wild Plants. New York, NY: Sterling Publishing Co., Inc., 2009, 69-70. ISBN 978-1-4027-6715-9.

8. Global Invasive Species Database: "Uses"- Retrieved 2017, 01-20.

9. Gore, A. B. Environmental Research at the Leading Edge. New York: Nova Science Publishers, Inc. p. 2007, 106.

10. Grace, J. B. and J. S. Harrison. The biology of Canadian weeds. 73. Typha Iatifolia L., Typha angustifolia $\mathrm{L}$. and Typha $\mathrm{x}$ glauca Godr. Can. J. Plant Sci. 1986, 66, 361- 379.

11. Grace, J. B. and Wetzel, R. G. Habitat partitioning and competitive displacement in cattails (Typha): experimental field studies. The American Naturalist 1981, 118, 463-74.

12. Kaminski, R. M., et al., Control of cattail and bulrush by cutting and floodin. In: Coastal Wetlands. 1985, 253-62., Lewis Publishers.

13. Keddy, P. A. Wetland Ecology: Principals and Conservation. Cambridge University Press. 2010, 497. ISBN 978-0-521-519404.

14. Maiden, J. H. Useful Native Plants of Australia (incl. Tasmania). Sydney: Technological Muse New South Wales, 1889.

15. Making Aquatic Weeds Useful: Some Perspectives for Developing Countries. Ottawa: National Research Council. Books for Business. 1976. p. 101. ISBN 0-89499-180-9.

16. Marsh, L. C. "The Cattail Story". The Garden Journal. 1959, 5, 114-129.

17. Miller, D. T. Edible and Useful Plants of Texas and the Southwest, Including Recipes, Harmful Plants, Natural Dyes, and Textile Fibers: A Practical Guide. Austin: University of Texas Press. 1999, 147. ISBN 97870-292-78164-1.
18. Mitch, L. M. Common cattail, Typha latifolia L. Weed Technology. 2000, 14, 446-450.

19. Morton, J. F. "Cattails (Typha spp.) Weed Problem or Potential Crop?". Economic Botany. 1975, 29 (1), 7-29. doi:10.1007/bf02861252.

20. Motivans, K. and S. Apfelbaum. Element stewardship abstract for Typha spp., North American cattails. The Nature Conservancy, 1987.

21. Murkin, H. R. and P. Ward. Early spring cutting to control cattail in a northern marsh. Wildlife Society Bulletin. 1980, 8, 254-256.

22. Oudhia, P. Allelopathic TEMPeffects of Typha angustata on germination and seedling vigour of winter maize and rice. Agric. Sci. Digest. 1999, 19(4), 285-286

23. Pawar CR, Kolhe VN \& Ithedkar PA Antiinflammatory Activity of leaves of Typha angustifolia (Typhaceac), IMAM, 2011, 2(5), 1598-1600.

24. Raupo or Bulrush (Typha orientalis). Tai Awatea. Accessed 15 December 2011.

25. Reed, E.; Marsh, L. C."The Cattail Potential". Chemurgic Digest. 1995, 3, 14: 9 ,

26. Revedin A et al., "Thirty thousand-year-old evidence of plant food processing". Proc Natl Acad Sci U S A. 2010, 107 (44), 18815-18819.

27. Shipley, B., et al., Regeneration and establishment strategies of emergent macrophytes. Journal of Ecology 1989, 77, 1093-1110.

28. Stevens, M. and C. Hoag. NRCS plant guide: Narrowleaf cattail, Typha angustifolia L. USDA, NRCS, National Plant Data Center and Idaho Plant Materials Center, 2000.

29. "Typha". Natural Resources Conservation Service PLANTS' Database. USDA, Retrieved 12 December 2015

30. Van der Valk, A. G., and Davis, C. B. The seed banks of prairie glacial marshes. Canadian Journal of Botany. 1976, 54, 1832-1838.

\section{Cite this article as:}

Amit Pandey and R.K. Verma. Taxonomical and Pharmacological Status of Typha: A Review. Annals of Plant Sciences 7.3 (2018) pp. 2101-2106.

http://dx.doi.org/10.21746/aps.2018.7.3.2 